\title{
Review: The Operation of International Law in the Russian Legal System
}

\author{
Maksim Likhachev ${ }^{\circledR}$, Yury Bezborodov* \\ International and European Law Department, Ural State Law University, Ekaterinburg, Russia \\ Email: m.a.likhadhev@gmail.com, *yu ry.bezborodov@gma il.com
}

How to cite this paper: Likhachev, M., \& Bezborodov, Y. (2019). Review: The Operation of International Law in the Russian Legal System. Beijing Law Review, 10, 474-479. https://doi.org/10.4236/blr.2019.103028

Received: March 4, 2019

Accepted: June 1, 2019

Published: June 4, 2019

Copyright () 2019 by author(s) and Scientific Research Publishing Inc. This work is licensed under the Creative Commons Attribution International License (CC BY 4.0).

http://creativecommons.org/licenses/by/4.0/

\begin{abstract}
This work is the author's review of the monograph "The Operation of International Law in the Russian Legal System. A Changing Approach" by the well-known Russian international lawyer S. Yu. Marochkin, which was published in 2019 in the oldest European publishing house, Brill Nijhof. Being deep in content and possessing qualitative analysis of legal material, this book raises the bar for the research of the interrelation between international and domestic law to practically unattainable heights. Most importantly, this treatise introduces these developments to numerous English-speaking readers and aims to bring together a scattered and divided academical community.
\end{abstract}

\section{Keywords}

Interaction of International and Domestic Law, Transformation, Direct Application of International Legal Norms, Implementation of International Law, Priority of Application

\section{Introduction}

Since the academic ostracism and deep bipolarity of the today world appear to be evident and even ineradicable, publication of Russian academic's treatise worldwide (especially in the West) is a significant event of the scientific life. Even though the science should be universal and expand beyond frontiers, Western academics are not so interested in the non-Western doctrine. The same situation exists in international law. Only a few Russian theorists and fundamental treatises are broadly known to Western audience. Probably the most famous treatise is Tunkin's Theory of International Law (Butler, 1974). This paper is devoted to professor Marochkin's book considered to be a great contribution to the doctrine of international and domestic law interaction and which would probably be the next Russian academic work known worldwide. 


\section{The Evolution of Marochkin's Views}

Forty-five years after the publication of the prominent Tunkin's work, the oldest European publishing house (est. in 1683) edited the monograph by S. Yu. Marochkin "The Operation of International Law in the Russian Legal System. A Changing Approach". The book is the result of many years research of the professor Marochkin in the doctrine of the interaction of international and domestic law. This monograph is deemed to be a sequel of another S. Yu. Marochkin's work "Operation and Realization of the International Law norms in the Legal System of the Russian Federation", which is well-known among Russian readers (Marochkin, 2011). Anyway, the new book is not the English version of the mentioned treatise. The author conducted considerable refinement of the material and significantly widened the empirical basis of the analysis, because since the 2011 Russian legal reality had substantially changed.

The 2019 S. Yu. Marochkin's book appears to be an autonomous and sophisticated work with logically gauged structure and nuanced practical recommendations, which demonstrates the essence of the author's theory of international and internal law interaction. The problem raised by the professor in his treatise is highly topical since "last thirty years the Russian approach to the international law within domestic jurisdiction changed" (Marochkin, 2019: p. 291).

\section{Marochkin's Ideas Today}

S. Yu. Marochkin's monograph has some undeniable key points, which confirm consistency of the author's position in comparison to other works on the same topic. First of all, the author technically differentiate the tools by means of which international law operates within the domestic legal order; he introduces legal conditions of that operation (Marochkin, 2019: pp. 107-137), its normative and structural basis (Marochkin, 2019: pp. 142-149, 155-197, 227-239), forms, spheres and function of the international law application on the domestic level (Marochkin, 2019: pp. 197-227), variants and schemes of the application (Marochkin, 2019: pp. 149-155). Although these terms and tools are more pertinent to the Russian theory of international law, they provide a description of the universal technique of international legal rules' operation within internal order.

The survey of the mentioned terms and tools is preceded by the analysis of theoretical and constitutional basics of the international law implementation into domestic legal order. The author dwells upon the dichotomy and contraventions of the following main doctrines of international law operation within domestic legal order: these are transformation theory and theory of direct operation of the international legal norms. He consequently concludes that such contraposition is useless. S. Yu. Marochkin asks the rhetorical question: "Do supporters of 'transformation' and 'direct application' hold opposing views?" [p. 40]. Such opposition has a long history in the Russian theory of international law. The proponents of the transformation theory believe that international rules are operative in the internal order only via domestic rules (Chernichenko, 2014: 
p. 193); (Vasilenko, 1988: p. 194); (Makovskiy, 1994: p. 108). For the application of an international treaty in the domestic proceedings it is necessary to demonstrate that some rights or duties prescribed in international law are implemented into domestic legal order by some internal rules. Otherwise the international rule is void for domestic courts. On the contrary the supporters of the direct operation theory insist on the self-executing character of international rules: domestic courts abide by any international legal provision accepted by the State (Blishchenko, 1991: p. 135); (Blishchenko \& Solntseva, 1991: pp. 103-104). The discrepancy between these two approaches is very close to dualism and monism dichotomy.

We do agree with professor that “'transformation' does not always mean 'conversion' of [international law] norms into domestic ones-the accepting, changing or cancellation of the domestic legal norms in order to bring them into compliance with commitments under [international law]", "[o]n the other hand, 'direct application' is incorrectly interpreted by its opponents as an automatic operation of [international law] norms in the territory beyond the state's will" (Marochkin, 2019: p. 41).

\section{Composition of the Book}

The book consists of three parts. The first one called "Norms and Sources of International Law in the Legal System of the Russian Federation" deals with the functions of such rules and acts in the domestic legal order. The author analyses the Russian Constitution's current and previously existing provisions concerning interrelation between international norms and the Russian legal system (chapter I “A Fleeting Glance Back"), and a doctrinal definition of the legal system and its content (chapter II "On the Concept of National and International Legal Systems"). Also the Part I of the monograph addresses the following issues: the theory of the international and internal law interaction, hierarchy of the different types of Russian treaties and its precedence over domestic legal acts, nature of the international law rules in the national legal order, and the legal force of the norms of both legal systems.

The Part II "Legal and Organizational Basics for Operation and Realization of International Law Norms in the Legal System of the Russian Federation" is more practically oriented. It deals with the legal and structural basis of the international rules' application and operation in the domestic legal order of the Russian Federation. The author explains the legal grounds of the aforementioned rules' operation, discloses the nature of the blanket norms and describes how they influence the internal implementation of international law. Also S. Yu. Marochkin emphasizes the mechanism of such implementation and finally shows how all this system functions on the federal, regional and local scale.

The Part III "Practical Aspects of the Operation and Realization of International Norms in the Legal System of the Russian Federation" focuses on material and procedural challenges to the international law's operation and application in the Russian legal system. The author presents a nuanced and peculiar analysis of the operation of non-compulsory international norms in the domestic legal sys- 
tem: treaties that are not in force for Russia and acts of international organizations, including those which Russia is not a member of.

Final chapter XIV “The Issue under Study through the Prism of International and National Rule of Law" concerns the basic principle of the Rule of Law which "has become a stated point of the UN General Assembly agenda through the prism of the relationship between [international law] and domestic law" (Marochkin, 2019: p. 83). S. Yu. Marochkin concludes that the real approaches of the states to international law and important aspects of the international interaction as a whole are often contrary to this principle. In this respect he writes: "Acute world problems and disasters are actually the agony and crisis not primarily of international law, but of the backward viewpoint of states and their attitude towards one other, their desire for domination and superiority rather than restraint, tolerance, and equal opportunities on the basis of law" (Marochkin, 2019: p. 290). And such tendencies occur regardless the states' proclaimed commitment to the Rule of Law.

\section{Merits of the Text}

The distinction of the book is its terminological accuracy. The author describes the place of the Russian international treaties in the framework of the Russian legal sources. The professor rigorously differentiates the latter from the sources of international law: "while [the sources of international law] are considered to be part of the legal system, the Constitution does not at all specify their place in a number of the domestic law sources. In other words, the [international law] sources are specified within the regulatory part of the [Russian Federation] legal system-they operate in the neighborhood, close to and alongside the domestic law sources, in concert with them-but they are not "incorporated" into the national legal pool" (Marochkin, 2019: p. 64).

Marochkin's new book, being deep in the analysis and rich in its theoretical and empirical basis, significantly raises the level of the research of the interrelation between international and domestic law. It familiarizes foreign researchers with the achievements of the Soviet and Russian doctrine on this issue. The professor emphasizes the role of the Rule of Law as a core principle for governance and legal processes of each state. S. Yu. Marochkin concludes his monograph with the thesis: "The path to the rule of law is long and hard; it still requires drastic changes in the will and mentality of the state" (Marochkin, 2019: p. 293).

S. Yu. Marochkin is a fervent proponent of the non-self-executing treaties doctrine (Marochkin, 2019: pp. 227-238). Such approach in its traditional sense excludes the domestic implementation of treaties without adoption of corresponding internal legal acts. The doctrine has a solid basis in the Russian legal norms ${ }^{1}$ and the directives of the Russian Supreme Court ${ }^{2}$. Nevertheless, trying to

${ }^{1}$ Russian Federal Law on International Treaties 1995 (art. 5), Russian Civil Code 1994 (art. 7 (2), Part I).

${ }^{2}$ Regulation of the Russian Supreme Court on the Implementation of the Generally Recognized Principles and Norma of International Law and International Treaties of the Russian Federation by the General Courts 2003 (par. 3). 
dispute the author's point one needs to refer to the strict Russian Constitution's provisions. The Constitution declares the generally recognized norms and principles of international law and international treaties of the Russian Federation are an integral part of the Russian legal system without any additional requirements and preconditions. Therefore the absence of any indication of the applicability of certain international norms to domestic relations, the absence of the norms to be strictly addressed to legal and physical entities and particular bodies, and the lack of implementation mechanism cannot be regarded as impediments to direct implementation of an international treaty in the Russian legal order (Marochkin, 2019: pp. 234-238). Nevertheless, it can significantly complicate such operation (Likhachev, 2017: pp. 68-74).

\section{Conclusion}

Taking dualistic or monistic approach, one cannot neglect the interaction of international and domestic law and their strengthening correlation. This is the essence of the Marochkin's book. However, the value of the reviewed monograph is also determined by the topicality of the conducted research, the depth of the current Russian practice analysis and its availability to the international audience. Nowadays, in light of the conflict between European (Council of Europe) and Russian legal orders, such works and other doctrinal contributions aimed to balance political controversies are helpful and highly-demanded. They facilitate mutual understanding and interchange of positions concerning contemporary legal challenges. Thus, we do hope that this monograph will be a solid ground for subsequent theoretical and practical research by western and eastern academics as it appears to be in Russia.

\section{Conflicts of Interest}

The authors declare no conflicts of interest regarding the publication of this paper.

\section{References}

Blishchenko, I. P. (1991). Nekotorie Problemi Sovietskoyi Nauki Mezhdunarodnogo Prava, 3 Sovietskoye Gosudarstvo I Pravo. Moscow.

Blishchenko, I. P., \& Solntseva, M. M. (1991). Mirovaya Politika i Mezdunarodnoe Pravo. Moscow.

Butler, W. E. (1974). Theory of International Law by Tunkin G. I. Cambridge, Mass.: Harvard University Press.

Chernichenko, S. V. (2014). Konturi Mezhdunarodnogo Prava. Obshie Voprosy. Moscow.

Likhachev, M. A. (2017). Realizatsiya mezhdunarodnykh standartov prav cheloveka sudami RF [The Realization of Human Rights International Standards by Russian Courts], RUDN Publ.

Makovskiy, A. L. (1994). Mezhdunarodnoe Chastnoe Pravo: Sovremennie Problemi. Moscow. 
Marochkin, S. Y. (2011). Deistviya i realizatsiya norm mezhdunarodnogo prava v pravovoi sisteme Rossiiskoi Federatsii. Moscow. Norma: INFRA-M.

Marochkin, S. Y. (2019). The Operation of International Law in the Russian Legal System. A Changing Approach by Sergey Yu. Marochkin. Leiden, Boston: Brill Nijhof. https://doi.org/10.1163/9789004391017

Vasilenko, V. A. (1988). Osnovi Teorii Mezhdunarodnogo Prava. Kiev. 